\title{
Hypovitaminosis D in pregnancy: Is it a public health issue?
}

José Rogério de Jesus Linhares de Souza 1

https://orcid.org/0000-0003-3752-8792

Tatyana Santana de Azevedo Silva 2

https://orcid.org/0000-0002-3218-070X

Eduardo Durans Figueredo 3

https://orcid.org/0000-0001-7739-6400

1-3 Universidade Ceuma. Campus Renascença. Rua Josué Montello, n 1, Renascença II. São Luís, MA, Brasil. CEP 65.075-120. E-mail: edufigueredo@terra.com.br

\begin{abstract}
Objectives: to measure the prevalence of hypovitaminosis $D$ in healthy pregnant women and to analyze the association among some variables and the levels of vitamin D.

Methods: an analytical cross-sectional study. 174 healthy pregnant women were selected from four basic health units in São Luís, Brazil, from January to February 2017. The participants answered a questionnaire about sociodemographic and obstetric data. A blood sample was collected to evaluate the plasmatic level of vitamin D. The association between independent variables and the outcome was evaluated by using the Student's t-test and Chi-square test.

Results: the mean of vitamin D concentration was $24.9 \pm 6.6 \mathrm{ng} / \mathrm{ml}$. Forty women (23.0\%) presented vitamin D sufficiency, 93 (53.4\%) insufficient, and 41 (23.6\%) with deficiency. There was a difference in the vitamin D concentration between evangelical $(23.1 \mathrm{ng} / \mathrm{ml})$ and non-evangelical $(25.5 \mathrm{ng} / \mathrm{ml})(p=0.02)$ and between primigravida $(23.8 \mathrm{ng} / \mathrm{ml})$ and non-primigravida $(25.7 \mathrm{ng} / \mathrm{ml})(\mathrm{p}=0.03)$. There was a difference in the hypovitaminosis $D$ between adolescents (89.7\%) and non-adolescents (72.6\%) $(p=0.02)$ and between primigravida (85.0\%) and non-primigravida (69.2\%) ( $p=0.01)$. Low monthly income per capita was associated with a higher frequency of vitamin D sufficiency.

Conclusions: Due to the impact of inadequate levels of vitamin $D$ in pregnant women and their babies' health, even in an equatorial city, hypovitaminosis D in pregnant women is an important public health issue.
\end{abstract}

Key words Vitamin D, Vitamin D deficiency, Pregnancy 


\section{Introduction}

Vitamin D is not in fact a vitamin, under proper conditions, it can be synthesized by human beings The synthesis begins with the oxidation of dietary cholesterol in the intestine, forming a 7-dehydroepicolesterol. This compound is then transported through the bloodstream up to the skin where under the effect of a solar ultraviolet $B$ (UVB) radiation, it is non-enzymatic form converted into vitamin $\mathrm{D}_{3}$ or Cholecalciferol. The synthesis accounts for approximately $90 \%$ of the total vitamin D in the organism. 1,2

The exposure of approximately $18 \%$ of the body's surface area equivalent to the arms and legs in sunlight for at least 15 minutes daily is sufficient to ensure an adequate vitamin D synthesis, 3 which can vary according to latitude, season of the year, skin color, use of sunscreen, cultural or religious factors, and so on.4,5

Numerous studies have revealed an association between maternal plasmatic levels of vitamin D and various pregnancy outcomes. At the time of fertilization, the level of vitamin D in mothers is associated to an increase in the success rate of assisted reproduction techniques. 6 Andersen et al. ${ }^{7}$ found that the risk of miscarriage was lower in pregnant women with normal levels of vitamin D. Vitamin D insufficiency is also associated to a higher occurrence of gestational diabetes, pre-eclampsia, small-for-gestational-age infants, preterm births and bacterial vaginosis. $8-10$

A systematic review carried out by Palacios and Gonzalez11 demonstrates the high prevalence of hypovitaminosis D worldwide, even in areas with abundant sunlight during practically the entire year, and the huge information gaps that still exist.

The lack of studies on the prevalence of hypovitaminosis D in healthy pregnant women in Latin America in general, in Brazil, and in particular in the Northeast region, motivated us to conduct this study, which aims to measure the prevalence of hypovitaminosis D (deficiency or insufficiency) in healthy pregnant women and to verify the association among demographic, socioeconomic and obstetric variables and plasmatic levels of vitamin D.

\section{Methods}

A quantitative, observational, analytical, crosssectional study was carried out in four Basic Health Units (BHU) in São Luís, MA (Brazil). The city of São Luís, capital of Maranhão state is located at a latitude of: $2^{\circ} 31^{\prime} 48^{\prime \prime} \mathrm{S}$, this is close to the equator. This region does have the two defined climatic seasons: a rainy summer and a dry winter. The duration of the day in São Luís does not vary significantly during the year, about 16 minutes more or less than 12 hours a year, in other words, the shortest day of the year has $11 \mathrm{~h} 44 \mathrm{~min}$ of sunlight, while the longest day has $12 \mathrm{~h} 16 \mathrm{~min} .{ }^{12}$

All healthy pregnant women, in other words, without comorbidities who received prenatal care at the selected BHU in the period of January and February of 2017 (beginning of summertime - rainy season) were invited to participate in this study. Pregnant women who used vitamin D supplementation at any point during their pregnancy prior to the data collection were not included in this study. At the end of the data collection, 174 women were included.

The data were collected by using a form filled out by a researcher. A blood sample was collected from the participants at a private laboratory in São Luís to measure the plasmatic dosage of vitamin D. The dosages of vitamin D levels were measured by using the ADVIA Centaur Vitamin D Total test (Siemens ${ }^{\circledR}$, Berlin, Germany).

All the data were entered in an MS-Excel ${ }^{\circledR}$ spreadsheet program (Microsoft, Charlotte, NC, USA) and then exported to Stata $12.0^{\circledR}$ program (Stata Corp, College Station, TX, USA) for statistical analysis. The qualitative variables were presented as absolute and relative frequencies, whereas the quantitative variables were presented as the mean and standard deviation. The association between the independent variables and the level of vitamin D was verified by the Student's t-test and Chi-square test. A value of $p<0.05$ was considered statistically significant.

This study used the following levels of vitamin D to classify as: sufficiency - plasmatic level greater or equal to $30 \mathrm{ng} / \mathrm{ml}$; insufficiency - plasmatic level greater or equal to $20 \mathrm{ng} / \mathrm{ml}$ and lower than 30 $\mathrm{ng} / \mathrm{ml}$; deficiency - plasmatic level lower than 20 $\mathrm{ng} / \mathrm{ml}$; and hypovitaminosis D - the presence of insufficient or deficiency of vitamin D. 13

As ethnicity can influence the production of vitamin D, two categories were created based on the skin color: dark skinned pregnant women, which included black, mixed and indigenous women; and light-skinned pregnant women, which corresponded to white women.

This study was approved by the Human Research Ethics Committee of Universidade Ceuma (CEPCeuma), Consolidated Document n. 1,593,090. All the collected data were carried out after the final approval of the project by CEP-Ceuma. All the patients or guardians when applicable, were 
informed about the risks and benefits of participating in the research, agreed to participate and signed an informed consent form. No data that could identify the patients were collected.

\section{Results}

A total of 174 healthy pregnant women with a mean age of $25.7 \pm 6.2$ years (age range of 14-40) were analyzed. Regarding to skin color, 148 (85.1\%) were dark-skinned, and 26 (14.9\%) were light-skinned. In relation to marital status, 120 women $(69.0 \%)$ lived with their partners. Regarding to religion, 94 participants $(54.0 \%)$ were Catholic, 49 (28.2\%) evangelic, one $(0.6 \%)$ was messianic, $26(14.9 \%)$ affirmed having no religion, and four $(2.3 \%)$ refused to answer. (Table 1)

The mean number of inhabitants per household was 3.8 people $(95 \%$ CI $3.6-4.1)$. The average monthly household income was R $\$ 1.290,25$ (US\$ 403.20) $(95 \%$ CI $1.185,09-1.395,42)$ which is equivalent toUS\$ $403,20 \quad(95 \% \mathrm{CI} \quad 370,34-436,06)$. Therefore, the average monthly per capita income was $\mathrm{R} \$ \quad 382,69 \quad$ (US\$ 119.59$) \quad(95 \% \quad$ CI $344.99-420.39)$ equivalent to US\$ $119,59(95 \%$ CI 107,80-131,37).

In total, 129 pregnant women (74.1\%) declared that they did not use sunscreen. According to life habits, five patients $(2.9 \%)$ affirmed to smoke, and two (1.1\%) regularly consumed marijuana (Cannabis $s p$ ), whereas alcohol consumption was referred by six participants (3.5\%).

One hundred and twenty women $(69.0 \%)$ were primigravida, and the mean gestational age was $20.8 \pm 9.6$ weeks (Table 2).

Table 1

\begin{tabular}{|c|c|c|}
\hline Variables & $\mathbf{N}$ & $\%$ \\
\hline \multicolumn{3}{|l|}{ Skin color / Ethnicity } \\
\hline White & 26 & 14.9 \\
\hline Indigenous & 2 & 1.2 \\
\hline Mixed & 108 & 62.1 \\
\hline Black & 38 & 21.8 \\
\hline \multicolumn{3}{|l|}{ Marital Status } \\
\hline With partner & 120 & 69.0 \\
\hline Without partner & 54 & 31.0 \\
\hline \multicolumn{3}{|l|}{ Religion } \\
\hline Evangelical & 49 & 28.2 \\
\hline Catholic & 94 & 54.0 \\
\hline Messianic & 1 & 0.6 \\
\hline Without religion & 26 & 14.9 \\
\hline Did not answer & 4 & 2.3 \\
\hline
\end{tabular}


The mean concentration of $25(\mathrm{OH}) \mathrm{D}$ was $24.9 \pm 6.6 \mathrm{ng} / \mathrm{ml}$. For the purpose of the analysis, the participants were divided into three categories: 40 women $(23.0 \%)$ had vitamin D sufficiency, 93 (53.4\%) had vitamin D insufficiency, and 41 (23.6\%) had vitamin D deficiency.

When analyzing the association among the sociodemographic and obstetric data and the mean of vitamin D concentration, a statistically significant difference was observed among the evangelical $(23.1 \mathrm{ng} / \mathrm{ml})$ and non-evangelical $(25.5 \mathrm{ng} / \mathrm{ml})$ $(p=0.02)$ and between primigravida $(23.8 \mathrm{ng} / \mathrm{ml})$ and non-primigravida $(25.7 \mathrm{ng} / \mathrm{ml})(p=0.03)$. The other variables (marital status, skin color, use of sunscreen and gestational trimester) did not present a statistically significant difference. (Table 3 )
When the association between the independent variables and hypovitaminosis D was analyzed, there was a statistically significant difference between adolescents $(89.7 \%)$ and non-adolescents $(72.6 \%)$ $(p=0.02)$ and between primigravida $(85.0 \%)$ and non-primigravida $(69.2 \%)(p=0.01)$. (Table 4$)$

In relation to hypovitaminosis $\mathrm{D}$ showed that there was a statistically significant difference when analyzing monthly income per capita. Among pregnant women with hypovitaminosis $\mathrm{D}$, the average monthly income per capita was $\mathrm{R} \$ 416,20(95 \% \mathrm{CI}$ $370.71-461.69$ ) equivalent to US\$130,06, whereas among those with vitamin D sufficiency, the average monthly income per capita was $\mathrm{R} \$ 273,99(95 \% \mathrm{CI}$ $222.53-325.44)$ which is equivalent to (US\$ 85.62) $(p<0.01)$

Table 2

Healthy 174 pregnant women's obstetric data - São Luís (2017).

\begin{tabular}{lcc}
\hline Variables & N & \\
\hline Gestational age & 46 & 26.4 \\
$\quad$ First Trimester & 71 & 40.8 \\
Second Trimester & 57 & 32.8 \\
$\quad$ Third Trimester & $20.8 \pm 9.6$ \\
Mean \pm SD* & 120 & 69.0 \\
Number of gestations & 54 & 31.0 \\
$\quad$ Primigravida & 54 \\
$\quad$ Non-primigravida & & \\
\hline
\end{tabular}

*Gestational age mean and standard deviation. 
Factors associated to the mean concentration of vitamin D in healthy 174 pregnant women in São Luís (2017).

\begin{tabular}{|c|c|c|c|c|}
\hline Variables & $\mathbf{N}$ & $\begin{array}{l}\text { Mean Concentration } \\
\text { of Vitamin D }(\mathrm{ng} / \mathrm{ml})\end{array}$ & $95 \% \mathrm{Cl}$ & $p^{*}$ \\
\hline \multicolumn{5}{|l|}{ Marital status } \\
\hline With partner & 120 & 24.4 & $23.2-25.5$ & \\
\hline Without partner & 54 & 25.9 & $24.0-27.7$ & 0.92 \\
\hline \multicolumn{5}{|l|}{ Skin color } \\
\hline Light & 26 & 24.2 & $21.8-26.5$ & \\
\hline Dark & 148 & 24.9 & $23.8-26.0$ & 0.71 \\
\hline \multicolumn{5}{|l|}{ Religion } \\
\hline Non-evangelical & 125 & 25.5 & $24.4-26.7$ & \\
\hline Evangelical & 49 & 23.1 & $21.2-25.0$ & 0.02 \\
\hline \multicolumn{5}{|l|}{ Use of sunscreen } \\
\hline No & 129 & 24.6 & $23.5-25.7$ & \\
\hline Yes & 45 & 25.5 & $23.4-27.6$ & 0.78 \\
\hline \multicolumn{5}{|l|}{ Number of gestations } \\
\hline Primigravida & 80 & 23.8 & $22.5-25.1$ & \\
\hline Non-primigravida & 94 & 25.7 & $24.2-27.1$ & 0.03 \\
\hline \multicolumn{5}{|l|}{ Gestational age } \\
\hline First Trimester & 46 & 26.3 & $24.2-28.5$ & \\
\hline Second Trimester & 71 & 24.2 & $22.8-25.6$ & \\
\hline Third Trimester & 57 & 24.4 & $22.6-26.2$ & 0.20 \\
\hline
\end{tabular}

* Student's t-test.

\section{Table 4}

Prevalence of hypovitaminosis D in relation to marital status, skin color, religion, use of sunscreen, adolescence, number of pregnancies and gestational trimester in healthy 174 pregnant women in São Luís (2017).

\begin{tabular}{|c|c|c|c|}
\hline \multirow{2}{*}{ Variables } & \multicolumn{3}{|c|}{ Prevalence of hypovitaminosis D } \\
\hline & $\mathrm{n}$ & $\%$ & $p^{*}$ \\
\hline \multicolumn{4}{|l|}{ Marital status } \\
\hline With partner & 91 & 75.8 & \\
\hline Without partner & 42 & 77.8 & 0.78 \\
\hline \multicolumn{4}{|l|}{ Skin color } \\
\hline Light & 22 & 84.6 & \\
\hline Dark & 111 & 75.0 & 0.28 \\
\hline \multicolumn{4}{|l|}{ Religion } \\
\hline Evangelical & 41 & 83.7 & \\
\hline Non-evangelical & 92 & 73.6 & 0.16 \\
\hline \multicolumn{4}{|l|}{ Use of sunscreen } \\
\hline Yes & 33 & 73.3 & \\
\hline No & 100 & 77.5 & 0.56 \\
\hline \multicolumn{4}{|l|}{ Adolescent } \\
\hline Yes & 35 & 89.7 & \\
\hline No & 98 & 72.6 & 0.02 \\
\hline \multicolumn{4}{|l|}{ Number of gestations } \\
\hline Primigravida & 68 & 85.0 & \\
\hline Non-primigravida & 65 & 69.2 & 0.01 \\
\hline \multicolumn{4}{|l|}{ Gestational trimester } \\
\hline First & 30 & 63.8 & \\
\hline Second & 58 & 82.4 & \\
\hline Third & 45 & 79.2 & 0.20 \\
\hline
\end{tabular}

*Chi-square test. 
Prevalence of vitamin D deficiency, insufficiency and sufficiency in relation to marital status, skin color, religion, use of sunscreen, adolescence, number of pregnancies and gestational age in healthy 174 pregnant women in São Luís (2017).

\begin{tabular}{|c|c|c|c|c|c|c|c|}
\hline \multirow{2}{*}{ Variables } & \multicolumn{2}{|c|}{ Deficiency } & \multicolumn{2}{|c|}{ Insufficiency } & \multicolumn{2}{|c|}{ Sufficiency } & \multirow{2}{*}{$p^{*}$} \\
\hline & $\mathrm{n}$ & $\%$ & $\mathrm{n}$ & $\%$ & $\mathrm{n}$ & $\%$ & \\
\hline \multicolumn{8}{|l|}{ Marital status } \\
\hline With partner & 32 & 26.7 & 59 & 49.1 & 29 & 24.2 & \\
\hline Without partner & 9 & 16.7 & 33 & 61.1 & 12 & 22.2 & 0.26 \\
\hline \multicolumn{8}{|l|}{ Skin color } \\
\hline Light & 7 & 26.9 & 15 & 57.7 & 4 & 15.4 & \\
\hline Dark & 34 & 23.0 & 77 & 52.0 & 37 & 25.0 & 0.56 \\
\hline \multicolumn{8}{|l|}{ Religion } \\
\hline Evangelical & 19 & 38.8 & 22 & 44.9 & 8 & 16.3 & \\
\hline Non-evangelical & 22 & 17.6 & 70 & 56.0 & 33 & 26.4 & 0.01 \\
\hline \multicolumn{8}{|l|}{ Use of sunscreen } \\
\hline Yes & 10 & 22.2 & 23 & 51.1 & 12 & 26.7 & \\
\hline No & 31 & 24.0 & 69 & 53.5 & 29 & 22.5 & 0.84 \\
\hline \multicolumn{8}{|l|}{ Adolescent } \\
\hline Yes & 9 & 23.0 & 26 & 66.7 & 4 & 10.3 & \\
\hline No & 32 & 23.7 & 66 & 48.9 & 37 & 27.4 & 0.06 \\
\hline \multicolumn{8}{|l|}{ Number of gestations } \\
\hline Primigravida & 20 & 25.0 & 48 & 60.0 & 12 & 15.0 & \\
\hline Non-primigravida & 21 & 22.3 & 44 & 46.8 & 29 & 30.9 & 0.04 \\
\hline \multicolumn{8}{|l|}{ Gestational trimester } \\
\hline First & 10 & 21.3 & 20 & 42.5 & 16 & 36.2 & \\
\hline Second & 17 & 24.3 & 41 & 58.1 & 13 & 17.6 & \\
\hline Third & 14 & 24.5 & 31 & 54.7 & 12 & 20.8 & 0.20 \\
\hline
\end{tabular}

${ }^{\star}$ Chi-square test.

When analyzing the association among the sociodemographic variables and the presence of vitamin D deficiency, insufficiency and sufficiency, a statistically significant difference was found between the evangelical and non-evangelical $(p=0.01)$ and between the primigravida and the nonprimigravida $(p=0.04)$. (Table 5)

\section{Discussion}

This study found a hypovitaminosis D prevalence of almost $80 \%$ in the analyzed sample.

The racial composition of the selected sample reflects the situation in Brazil as a whole and, in particular, in Maranhão State. The intense miscegenation explains the predominance of mixed women found. When mixed women $(62.0 \%)$, black women $(21.8 \%)$ and indigenous women $(1.2 \%)$ were together, $85 \%$ of the pregnant women were considered dark-skinned.

There was no statistically significant difference in the concentration of vitamin D among darkskinned and light-skinned pregnant women, which may be due to the fact that, although São Luís is a very sunny city, it is close to the line of the equator, also São Luís is quite warm with an annual temperature of approximately $27^{\circ} \mathrm{C}\left(80.6^{\circ} \mathrm{F}\right)$. For this reason, people avoid exposing themselves to the sun, looking for shaded areas throughout the day, using sun umbrellas when walking or even avoiding outdoor activities during the sunniest hours of the day. This phenomenon was observed by other authors, 14,15 but a study carried out in Riyadh, Saudi Arabia, seems to corroborate this hypothesis more firmly, because it found that pregnant women with greater sun exposure at dusk than at noon or in the morning had significantly less vitamin D deficiency. 16

Another potential impact on cutaneous vitamin D synthesis was the use of sunscreen, which was used by $25.9 \%$ of the pregnant women. However, this variable was also not significantly associated to 
the concentrations of vitamin $\mathrm{D}$, suggesting once again that the participants as a whole did not expose themselves sufficiently to sunlight, which reduces the possible impact of sunscreen, or they used sunscreen improperly or irregularly. 4

The evangelical religion was related to both a lower mean of vitamin D concentration and a higher prevalence of vitamin D deficiency. This difference was attributed to evangelical women wearing clothing that covered more their body, which would lead to lower production of vitamin $\mathrm{D}$ as a result of less skin area exposed to sunlight. An Israeli study found a difference in the prevalence of vitamin D insufficiency and deficiency when comparing orthodox and unorthodox Jewish pregnant women. ${ }^{17}$ Some studies comparing pregnant women who wore veils to those who did not wear veils also showed a significant difference in the concentration of vitamin D. 18,19

An inverse relationship was found between vitamin D sufficiency and the household income per capita. This finding can be attributed to the fact that pregnant women with lower household incomes may have occupations that require greater sun exposure. A study in Thailand seems to corroborate this hypothesis as it found that women with lower schooling level and household income had higher vitamin $\mathrm{D}$ values, likely due to greater sun exposure. 20,21

Gestational age was not associated to the changes in plasmatic levels of vitamin D. Although, a high prevalence of hypovitaminosis D was observed in all the pregnancy trimesters. Similarly, in a study performed in the city of Delhi, India, Marwaha et al.22 found no significant difference in the prevalence of hypovitaminosis D between pregnancy trimesters and also found a high prevalence of hypovitaminosis $\mathrm{D}$, which was further aggravated by the fact that $96.3 \%$ of the pregnant women studied had vitamin D deficiency.

Being primigravida was associated to a lower mean of concentration of vitamin D, a higher percentage of hypovitaminosis D and a lower percentage of vitamin D sufficiency, which was in agreement with the results from other authors. ${ }^{20,23-25}$

Pregnant adolescents had a higher percentage of hypovitaminosis D. Perhaps pregnant adolescents may tend to be more withdrawn and participate in fewer outdoor activities or even have less adherence to prenatal recommendations. Studies have shown that this age group seems to be more vulnerable to vitamin D deficiency. $26-29$

Therefore, even studies conducted in different cities, located in different latitudes, and with different ethnic groups and cultures show a very high prevalence of hypovitaminosis D, similar to that found in the present research, which was performed near the line of the equator, an area of maximum solar radiation throughout the year. This suggests that the main common factor in the hypovitaminosis $\mathrm{D}$ epidemic must be the lack of adequate exposure to sunlight imposed by the climate, culture or modern lifestyle.

The collection of epidemiological data by a single researcher, and all the plasmatic dosages performed in the same laboratory and with the same equipment, demonstrate that the results of this present study can be extended to the group of pregnant women in the region of São Luís and other cities with the same climatic and social characteristics.

The main limitation of this study was that its cross-sectional design did not allow the establishment of the cause and effect relationships between the analyzed variables and the plasmatic levels of vitamin $\mathrm{D}$, however the findings of the research suggest a strong association between them. Further longitudinal studies will be needed to confirm the findings of this present study.

Because of the impact of inadequate levels of vitamin D in pregnant women and their babies' health, hypovitaminosis $\mathrm{D}$ in pregnant women is an important public health issue.

\section{Authors' contributions}

Souza JRJL - Elaboration of research project, data collection and writing. Silva TSA - Bibliographic research, statistical analysis and final writing results and discussion. Figueredo ED - Research Coordinator. All authors approved the final version of the manuscript. 


\section{References}

1. Holick MF, MacLaughlin JA, Clark MB, Holick SA, Potts JT Jr, Anderson RR, Blank IH, Parrish JA, Elias P. Photosynthesis of previtamin D3 in human skin and the physiologic consequences. Science. 1980; 210 (4466): $203-$

2. Colonese F, Laganà AS, Colonese E, Sofo V, Salmeri FM, Granese R, Triolo O. The pleiotropic effects of vitamin D in gynaecological and obstetric diseases: an overview on a hot topic. Biomed Res Int. 2015; 2015: 1-11.

3. Wranicz J, Szostak-Węgierek D. Health outcomes of vitamin D. Part I. characteristics and classic role. Rocz Panstw Zakl Hig. 2014; 65 (3): 179-84.

4. Webb AR, DeCosta BR, Holick MF. Sunlight regulates the cutaneous production of vitamin D3 by causing its photodegradation. J Clin Endocrinol Metab. 1989; 68 (5): $882-7$.

5. Lichtenstein A1, Ferreira-Júnior M, Sales MM, Aguiar FB, Fonseca LA, Sumita NM, Duarte AJ. Vitamin D: nonskeletal actions and rational use. Rev Assoc Med Bras 2013; 59 (5): 495-506.

6. Pacis MM, Fortin CN, Zarek SM, Mumford SL, Segars JH Vitamin D and assisted reproduction: should vitamin D be routinely screened and repleted prior to ART? A systematic review. J Assist Reprod Genet. 2015; 32 (3): 323-35.

7. Andersen LB, Jørgensen JS, Jensen TK, Dalgard C, Barington T, Nielsen J, Beck-Nielsen SS, Husby S, Abrahamsen B, Lamont RF, Christesen HT. Vitamin D insufficiency is associated with increased risk of firsttrimester miscarriage in the Odense Child Cohort. Am J Clin Nutr. 2015; 102 (3): 633-8

8. Aghajafari F, Nagulesapillai T, Ronksley PE, Tough SC, O'Beirne M, Rabi DM. (2013) Association between maternal serum 25-hydroxyvitamin D level and pregnancy and neonatal outcomes: systematic review and metaanalysis of observational studies. BMJ. 2013; 346: f1169.

9. Bodnar LM, Platt RW, Simhan HN. Early-pregnancy vitamin D deficiency and risk of preterm birth subtypes. Obstet Gynecol. 2015; 125 (2): 439-47.

10. Sablok A, Batra A, Thariani K, Batra A, Bharti R, Aggarwa AR, Kabi BC, Chellani H. Supplementation of vitamin D in pregnancy and its correlation with feto-maternal outcome. Clin Endocrinol (Oxf). 2015; 83 (4): 536-41.

11. Palacios C, Gonzalez L. Is vitamin D deficiency a major global public health problem? J Steroid Biochem Mol Biol. 2014; 144PA: 138-45.

12. WeatherSpark.com. Condições meteorológicas médias de São Luís. [online]. Excelsior, USA; 2018. [acesso 23 nov 2018]. Disponível em: https://pt.weatherspark.com/y/ 30549/Clima-característico-em-São-Luís-Brasil-durante-oano

13. Maeda SS, Borba VZC, Camargo MBR, Silva DMW, Borges JLC, Bandeira F. Recommendations of the Brazilian Society of Endocrinology and Metabology (SBEM) for the diagnosis and treatment of hypovitaminosis D. Arq Bras Endocrinol Metab. 2014; 58 (5): 411-33.

14. Halicioglu O, Aksit S, Koc F, Akman SA, Albudak E, Yaprak I, Coker I, Colak A, Ozturk C, Gulec ES. Vitamin D deficiency in pregnant women and their neonates in spring time in western Turkey. Paediatr Perinat Epidemiol. 2012; 26 (1): 53-60.

15. Jani R, Palekar S, Munipally T, Ghugre P, Udipi S Widespread 25-hydroxyvitamin D deficiency in affluent and nonaffluent pregnant Indian women. BioMed research international. 2014; 892162: 1-8.

16. Al-Faris NA. High Prevalence of Vitamin D Deficiency among Pregnant Saudi Women. Nutrients. 2016; 8 (2): 77.

17. Mukamel MN, Weisman Y, Somech R, Eisenberg Z, Lanman J, Shapira I, Spirer Z, Jurgenson U. Vitamin D deficiency and insufficiency in Orthodox and non-Orthodox Jewish mothers in Israel. Isr Med Assoc J. 2001; 3 (6): 41921.

18. Gannagé-Yared MH, Chemali R, Yaacoub N, Halaby G. Hypovitaminosis D in a sunny country: relation to lifestyle and bone markers. J Bone Miner Res. 2000; 15(9): 185662.

19. Fenina H, Chelli D, Ben Fradj MK, Feki M, Sfar E, Kaabachi N. Vitamin D Deficiency is Widespread in Tunisian Pregnant Women and Inversely Associated with the Level of Education. Clin Lab. 2016; 62 (5): 801-6.

20. Islam MZ, Akhtaruzzaman M, Lamberg-Allardt $C$. Hypovitaminosis D is common in both veiled and nonveiled Bangladeshi women. Asia Pac J Clin Nutr. 2006; 15 (1): 817.

21. Pratumvinit B, Wongkrajang P, Wataganara T, Hanyongyuth S, Nimmannit A, Chatsiricharoenkul S, Manonukul K, Reesukumal K. (2015) Maternal Vitamin D Status and Its Related Factors in Pregnant Women in Bangkok, Thailand. PLoS One. 2015; 10 (7): e0131126.

22. Marwaha RK, Tandon N, Chopra S, Agarwal N, Garg MK, Sharma B, Kanwar RS, Bhadra K, Singh S, Mani K, Puri S. Vitamin $\mathrm{D}$ status in pregnant Indian women across trimesters and different seasons and its correlation with neonatal serum 25-hydroxyvitamin D levels. Br J Nutr. 2011; 106 (9): 1383-9.

23. Johnson DD, Wagner CL, Hulsey TC, McNeil RB, Ebeling $\mathrm{M}$, Hollis BW. Vitamin D deficiency and insufficiency is common during pregnancy. Am J Perinatol. 2011; 28 (1): 7 12 .

24. Shiraishi M, Haruna M, Matsuzaki M, Murayama R. Demographic and lifestyle factors associated with vitamin D status in pregnant Japanese women. J Nutr Sci Vitaminol (Tokyo). 2014; 60 (6): 420-8.

25. Parlak M, Kalay S, Kalay Z, Kirecci A, Guney O, Koklu E. Severe vitamin D deficiency among pregnant women and their newborns in Turkey. J Matern Fetal Neonatal Med. 2015; 28 (5): 548-51.

26. Davis LM, Chang SC, Mancini J, Nathanson MS, Witter FR, O'Brien KO. Vitamin D insufficiency is prevalent among pregnant African American adolescents. J Pediatr Adolesc Gynecol. 2010; 23 (1): 45-52.

27. Young BE, McNanley TJ, Cooper EM, McIntyre AW, Witter F, Harris ZL, O'Brien KO. Maternal vitamin D status and calcium intake interact to affect fetal skeletal growth in utero in pregnant adolescents. Am J Clin Nutr. 2012; 95 (5): 1103-12. 
28. Black LJ, Burrows SA, Jacoby P, Oddy WH, Beilin LJ, Chan She Ping-Delfos W, Marshall CE, Holt PG, Hart PH, Mori TA. Vitamin D status and predictors of serum 25hydroxyvitamin D concentrations in Western Australian adolescents. Br J Nutr. 2014; 112 (7): 1154-62.
29. Musson P, Collin J. Management of vitamin D deficiency in childhood and adolescence. Nurs Child Young People. 2015; 27 (9): 27-35.

Received on August 07, 2018

Final version presented on November 23, 2018

Approved on January 16, 2019 